\title{
Contribution of Economic Nano-materials and Industry By-Products to the Fresh and Hardened Properties of Cement Mortars
}

\author{
Osama Hodhod ${ }^{1}$ Zeinab Salah $^{2}$ Ibrahim S. Khalil ${ }^{3}$ Hamada Shoukry $^{4}$ \\ ${ }^{1}$ Professor, Structural Engineering Dept., Faculty of Engineering, Cairo University, Egypt, Cairo. \\ ${ }^{2}$ Professor, Building Materials Research and Quality Control Institute, Housing \& Building National Research Center (HBRC), Cai ro, Egypt. \\ ${ }^{3}$ Associate researcher, Concrete Structural Research Institute, Housing \& Building National Research Center (HBRC), Cairo, Egypt.
}

${ }^{4}$ Researcher, Building Physics Institute, Housing \& Building National Research Center (HBRC), Cairo, Egypt.

\begin{abstract}
This study aims at evaluating the influence of low cost nano materials including; nano silica (NS) and nano clay (NC) and various industry by-products including; silica fume (SF), Fly ash (FA), and fine Air-Cooled Slag (FACS) as cement replacements on the compressive strength, flexural strength and rheological properties of cement mortars. The results revealed that, the investigated industrial by-products contribute to the strength development by various ratios at various replacement percentages. The best mechanical performance was obtained for the mortar incorporating $15 \mathrm{wt}$. $\%$ SF; remarkable enhancements by about 30.8 and 26.8 were obtained for the compressive and flexural strengths respectively as compared with the plain ordinary mortar. FACS showed insignificant contribution to both compressive and flexural strengths. Even at low levels of replacement; the nano-materials provide better enhancements of the mechanical strength. Incorporation of $3 \mathrm{wt}$. \% NS into the cement mortar has increased the compressive strength by about $38.5 \%$; while, the incorporation of $5 \mathrm{wt} \%$ of activated $\mathrm{NC}$ has considerably increased the flexural strength by $59 \%$ as compared to the ordinary cement mortar at 28 days of hydration. The workability of the blended mortars decreases with the loading of silica fume, fine air cooled slag nano-silica and nano-clay while increases with using fly ash and marble dust. The nano materials showed noticeable improvement of the structural integrity and microstructure, confirming the enhanced durability characteristics.
\end{abstract}

Keywords: Cement mortar, industry by-products, nano-silica, nano-clay, compressive strength, flexural strength, microstructure

\section{INTRODUCTION}

Globally, management of solid wastes poses a herculean challenge to developed and developing countries owing to industrial growth, construction booms, rapid urbanization, and consumeric lifestyle, The present high demand for natural resources to meet infrastructural demands has created immense opportunities for the use of waste materials to green infrastructure construction, These waste materials play the roles of either supplementary cementitious materials (SCM) or alternative aggregates in green concrete and can be categorized as agricultural, industrial and municipal wastes Many waste materials can be used to utilize their pozzolanic properties in green, the waste materials are often activated through physical or chemical means or their combination ${ }^{[1-4]}$ One of the most pollutant materials is cement as, Approximately 3.6 billion tons of cement is produced globally every year. A conservative estimate for every $1 \mathrm{~kg}$ of cement produced gives a by-product of $0.9 \mathrm{~kg}$ of carbon dioxide, this equates to 3.24 billion tons of $\mathrm{CO} 2$ per year. From the combustion fuel used to heat the raw materials to sintering temperatures (1400-1600 C). The theoretical heat requirement for clinker-making is calculated to be about $1.75 \pm 0.1 \mathrm{MJ}$ per $\mathrm{kg}{ }^{[5-7]}$. First step to reduce this source of pollution with reducing its amount in concrete, mortar and other construction purposes, using Supplementary cementations materials (SCMs) can achieve that were partially replacing by cement content, as Supplementary cementations materials can be used either as fillers or for their pozzolanic properties. They are composed of amorphous aluminosilicates, which react with excessive hydrated lime produced during cement hydration to form calcium aluminosilicate phase $\mathrm{C}-\mathrm{A}-\mathrm{S}-\mathrm{H}^{[\mathbf{8}-10]}$. In Egypt most of the SCM is an industrial waste, which occure in Egypt with a large amount, as Solid Waste Management in Egypt (2013), 89.03 tons of solid waste, 6 million of which is an industrial waste. The number of industrial enterprises in Egypt is approximately 64,997 with industrial sectors in 2011 representing $37.6 \%$ of Egypt's GDP (Gross Domestic Product). This sector "impacts environmental degradation in Egypt to a substantial extent" with a steady increase in the amount of industrial waste produced in Egypt over the years. Initiatives to tackle the issue such as "Green Growth" [11],[12], as improper solid waste management leads to substantial negative environmental impacts, including health and safety problems such as diseases associated with different forms of pollution $^{[6]}$.

\section{RELATED WORK}

An extensive research has been done all over the world in order to utilize and reuse the industry by-products in various construction applications. The addition of $10 \%$ silica fume has been found to increase the compressive strength of concrete cured at normal conditions [14], replacing cement by $5 \%$ marble dust could be a real energy and financial saving 
concept, in addition to saving part of the natural resources and alleviating the environmental [15], it can be replaced with sand to achieve adequate early compressive strength ${ }^{[16]}$, when cement is replaced with marble powder up to10\% weight a high strength concrete was achieved [17, 18]. impact imposed by the marble processing waste that the mix with nano-Silica from $1.5,3,5$ or $7 \%$ or with nano-clay(by activated or inactivated phase) and Silica Fume 10\%, increase in Compressive and flexure of concrete Strength and other properties $^{[19,20]}$. SCM and nano-materials not only fill microstructure pores but also act as Pozzolanic materials actively react with the $\mathrm{CH}$ from the hydration of the cement paste through the Pozzolanic reaction to produce more $\mathrm{C}-\mathrm{S}-\mathrm{H}$, and more homogenous and stronger interfacial zone [21], [22], [23], and [24].

\section{EXPERIMENTAL PROGRAM}

\section{III.I Materials and Mix Proportions:}

Materials employed through this investigation, natural sand, cement, silica fume, fly ash, marble dust, air cooled slag, nano-silica, nano-clay(activated and inactivated), water.

Materials employed through this investigation, natural sand, cement, silica fume, fly ash, marble dust, air cooled slag, nano-silica, nano-clay(activated and inactivated), water. The cement used is Portland cement, (PC), (CEM I 42.5 - N). The employed fine aggregate in this investigation is natural siliceous sand from local quarry in Giza, it has a fineness modulus of 2.5. According to the grading shown in Figure (1), its particle size distribution lies within the range of fine grading zone according to the classification of the Egyptian code of practice for design of concrete structures (ECP 2032007)[25], as it tested according to ASTM C136-96 standards [26]. Silica fume (SF) used in this study is a by-product of the production of silicon and ferrosilicon alloys. The used silica fume is locally produced and commercially available through metallurgical and construction chemical company. The chemical compositions are given in Table (1).

Table1. Chemical compositions of the starting raw materials

\begin{tabular}{|c|c|c|c|c|c|c|}
\hline Oxide & $\begin{array}{l}\text { CEM 1 } \\
\text { (\% wt.) }\end{array}$ & $\begin{array}{c}\text { SF } \\
(\% w t .)\end{array}$ & $\begin{array}{c}\text { FA } \\
\text { (\%wt.) }\end{array}$ & $\begin{array}{l}\text { FACS } \\
\text { (\%wt.) }\end{array}$ & $\begin{array}{c}\text { MD } \\
\text { (\%wt.) }\end{array}$ & $\begin{array}{c}\text { NC } \\
(\% \text { wt. })\end{array}$ \\
\hline $\mathrm{CaO}$ & 63.3 & 0.24 & --- & 41.2 & 43.5 & 16 \\
\hline $\mathrm{SiO}_{2}$ & 20.7 & 96.1 & 57.4 & 32.4 & 5.1 & 61.42 \\
\hline $\mathrm{Al}_{2} \mathrm{O}_{3}$ & 4.63 & 1.31 & 9.6 & 12.3 & 0.5 & 20.89 \\
\hline $\mathrm{Fe}_{2} \mathrm{O}_{3}$ & 3.63 & 0.57 & 6.1 & 0.6 & 0.7 & 1.06 \\
\hline $\mathrm{MgO}$ & 1.63 & 0.23 & 3.1 & 5.5 & 14.6 & 0.22 \\
\hline $\mathrm{SO}_{3}$ & 3.25 & ---- & 5.91 & --- & 0.04 & 0.17 \\
\hline $\mathrm{K}_{2} \mathrm{O}$ & 0.87 & 0.43 & 5.58 & --- & 0.03 & 1.61 \\
\hline $\mathrm{Na}_{2} \mathrm{O}$ & 0.21 & 0.05 & 0.55 & --- & 0.1 & 0.71 \\
\hline $\mathrm{TiO}_{2}$ & --- & ---- & --- & --- & --- & 0.70 \\
\hline $\mathrm{P}_{2} \mathrm{O}_{5}$ & --- & ---- & --- & --- & --- & 0.12 \\
\hline $\mathrm{KO}_{2}$ & --- & --- & 1.077 & --- & --- & --- \\
\hline $\begin{array}{l}\text { Ignition } \\
\text { Loss }\end{array}$ & 1.78 & 1.07 & --- & --- & 33.1 & --- \\
\hline
\end{tabular}

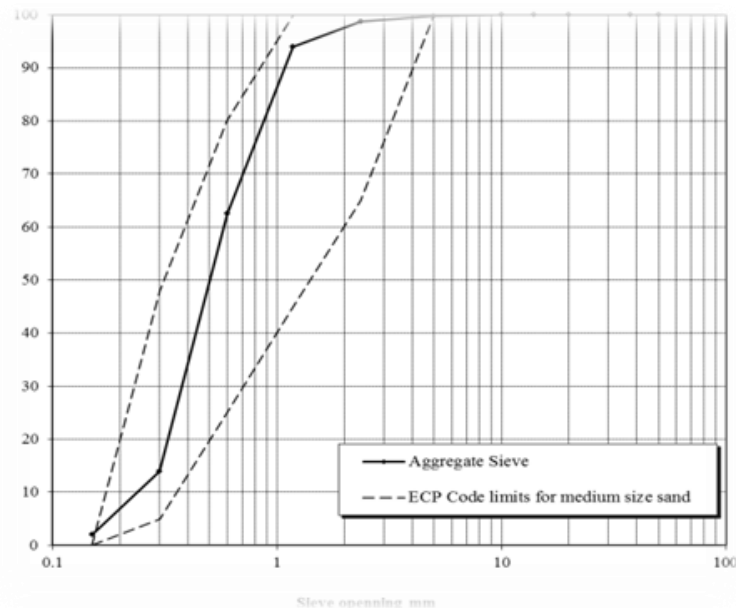

Fig. 1. Fine Aggregate Grading Curve according to ECP Code

Fly ash (FA) is a combustion residue (coal mineral impurities) in coal-burning electric power plants, which flies out with the flue gas stream and is collected by mechanical separators, electrostatic precipitators or bag filters. In this research a byproduct material from the electric power station in SuezEgypt was used. According to the chemical properties of flyash, introduced in table (1) the used fly ash is classified as class (F) in accordance with ASTM C618-12a limits [27].

FACS is a by-product from Iron and Steel Factory in HelwanEgypt., its grading conforms to standard limits.

Nano silica used in this research was locally produced by twophase processing. Phase 1 by chemical preparation, and phase 2 by mechanical grading to get a fair dispersion for nano particles. The mean particle size is $38 \mathrm{~nm}$. The TEM image is introduced in fig. 2 .

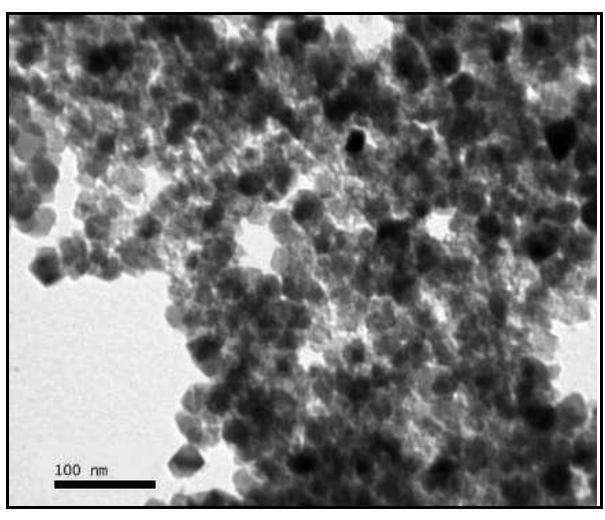

Fig.2. TEM of NS

The used nano clay type is supplied in the form of modified montmorillonite (hydrated sodium calcium aluminum silicate). It is a natural montmorillonite modified with an ammonium salt. The nano montmorillonite clay in its inactivated state is characterized by large length to thickness aspect ratio as shown in figure (3); it is especially favorable in matrix reinforcement. The mineral platelet thickness is only 1 $10 \mathrm{~nm}$, although its dimensions in length and width can be measured in hundreds of nanometers. 
International Journal of Engineering Research and Technology. ISSN 0974-3154, Volume 13, Number 8 (2020), pp. 1909-1916

(C) International Research Publication House. https://dx.doi.org/10.37624/IJERT/13.8.2020.1909-1916

The nano-clay was thermally treated at $800^{\circ} \mathrm{C}$ for 2 hours to give active amorphous nano montmorillonite clay. figure (4) presents TEM of activated nano montmorillonite clay particles.

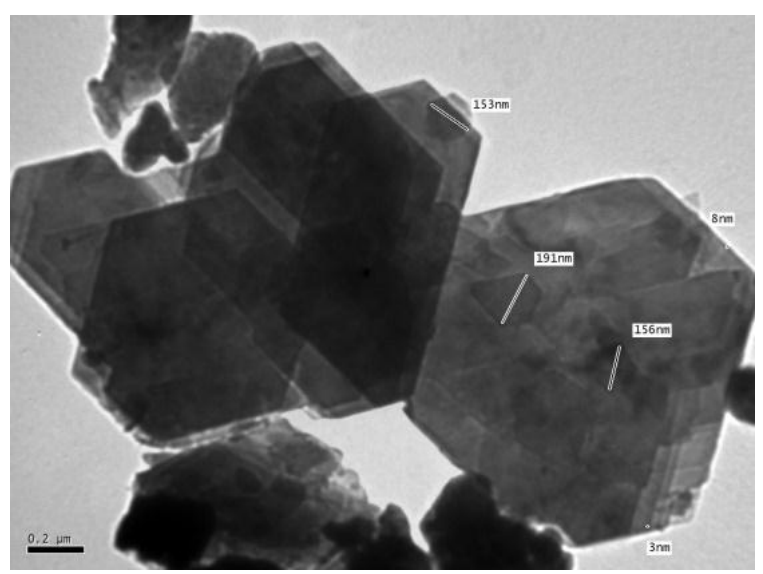

Fig. 3. TEM of as received NC

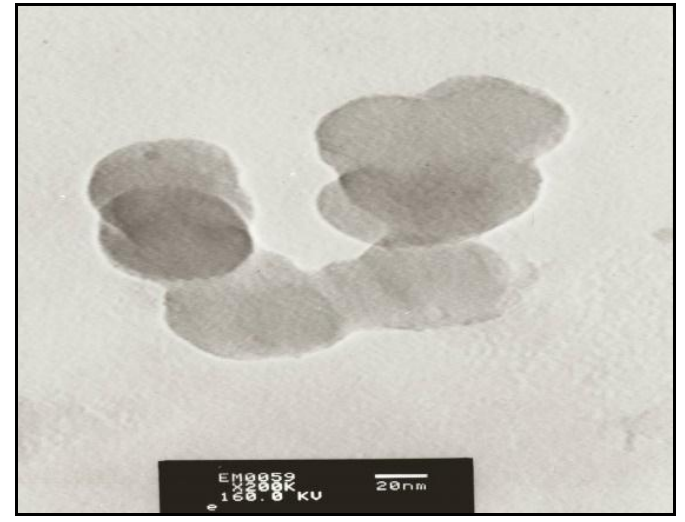

Fig. 4. TEM of activated NC

\section{III.II Test Program and Specimens Fabrication}

The by-product pozzolanic materials were grinded to be suitable for use as a cement replacement in mortar mixes. The mix designation of the investigated blended mortars is introduced in table (2).

\begin{tabular}{|c|c|c|c|c|c|c|c|c|c|c|}
\hline \multirow[b]{2}{*}{ Mix } & \multirow[b]{2}{*}{$\begin{array}{c}\text { C.C } \\
\%\end{array}$} & \multicolumn{3}{|c|}{ Nano materials } & \multicolumn{2}{|c|}{ By-product } & \multirow[b]{2}{*}{ Sand \% } & \multirow[b]{2}{*}{$\begin{array}{l}\mathbf{W} \\
\%\end{array}$} & \multirow[b]{2}{*}{ Curing } & \multirow[b]{2}{*}{$\mathbf{w} / \mathbf{b}$} \\
\hline & & $\begin{array}{c}\text { NS } \\
\%\end{array}$ & $\begin{array}{c}\mathrm{ANC} \\
\%\end{array}$ & $\begin{array}{c}\text { INC } \\
\%\end{array}$ & Type & $\%$ & & & & \\
\hline M1 & 100 & 0 & 0 & 0 & --- & --- & 275 & 48.5 & $\mathrm{~W}$ & 0.485 \\
\hline M2 & 95 & 0 & 0 & 0 & FA & 5 & 275 & 48.5 & $\mathrm{~W}$ & 0.485 \\
\hline M3 & 90 & 0 & 0 & 0 & FA & 10 & 275 & 48.5 & $\mathrm{~W}$ & 0.485 \\
\hline M4 & 85 & 0 & 0 & 0 & FA & 15 & 275 & 48.5 & $\mathrm{~W}$ & 0.485 \\
\hline M5 & 95 & 0 & 0 & 0 & SF & 5 & 275 & 48.5 & W & 0.485 \\
\hline M6 & 90 & 0 & 0 & 0 & SF & 10 & 275 & 48.5 & $\mathrm{~W}$ & 0.485 \\
\hline M7 & 85 & 0 & 0 & 0 & SF & 15 & 275 & 48.5 & $\mathrm{~W}$ & 0.485 \\
\hline M8 & 95 & 0 & 0 & 0 & FACS & 5 & 275 & 48.5 & $\mathrm{~W}$ & 0.485 \\
\hline M9 & 90 & 0 & 0 & 0 & FACS & 10 & 275 & 48.5 & $\mathrm{~W}$ & 0.485 \\
\hline M10 & 85 & 0 & 0 & 0 & FACS & 15 & 275 & 48.5 & $\mathrm{~W}$ & 0.485 \\
\hline M11 & 80 & 0 & 0 & 0 & FACS & 20 & 275 & 48.5 & $\mathrm{~W}$ & 0.485 \\
\hline M12 & 75 & 0 & 0 & 0 & FACS & 25 & 275 & 48.5 & $\mathrm{~W}$ & 0.485 \\
\hline M16 & 96 & 0 & 0 & 0 & FA & 6 & 275 & 48.5 & W & 0.485 \\
\hline M17 & 96 & 0 & 0 & 0 & FACS & 6 & 275 & 48.5 & $\mathrm{~W}$ & 0.485 \\
\hline M19 & 99 & 1 & 0 & 0 & --- & --- & 275 & 48.5 & $\mathrm{~W}$ & 0.485 \\
\hline M20 & 97 & 3 & 0 & 0 & --- & --- & 275 & 48.5 & $\mathrm{~W}$ & 0.485 \\
\hline M21 & 95 & 5 & 0 & 0 & --- & --- & 275 & 48.5 & $\mathrm{~W}$ & 0.485 \\
\hline M22 & 93 & 7 & 0 & 0 & --- & --- & 275 & 48.5 & $\mathrm{~W}$ & 0.485 \\
\hline M23 & 99 & 0 & 1 & 0 & --- & --- & 275 & 48.5 & $\bar{W}$ & 0.485 \\
\hline M24 & 97 & 0 & 3 & 0 & --- & --- & 275 & 48.5 & $\mathrm{~W}$ & 0.485 \\
\hline M25 & 95 & 0 & 5 & 0 & --- & --- & 275 & 48.5 & $\mathrm{~W}$ & 0.485 \\
\hline M26 & 93 & 0 & 7 & 0 & --- & --- & 275 & 48.5 & $\mathrm{~W}$ & 0.485 \\
\hline M27 & 99 & 0 & 0 & 1 & --- & --- & 275 & 48.5 & W & 0.485 \\
\hline M28 & 97 & 0 & 0 & 3 & --- & --- & 275 & 48.5 & $\mathrm{~W}$ & 0.485 \\
\hline M29 & 95 & 0 & 0 & 5 & --- & --- & 275 & 48.5 & $\mathrm{~W}$ & 0.485 \\
\hline M30 & 93 & 0 & 0 & 7 & --- & --- & 275 & 48.5 & $\mathrm{~W}$ & 0.485 \\
\hline
\end{tabular}




\section{RESULTS}

\section{IV.I. Effect of Silica fume /Cement Percentage (SF/C \%)}

Figures $(5,6 \& 7)$ show the effect of using silica fume as a cement replacement with constant cement content. The strength enhancement is a result of increasing the bond strength of cement paste aggregate interface by means of byproduct reaction and the filing effect of silica fume particles. The Figures show that the optimum percentage of silica fume was $15 \%$ except 3 days compressive strength as the increase was $6.8 \%, 28.8 \%$ and $30.8 \%$ for $5 \%, 10 \%$ and $15 \%$ respectively, for $10 \%$ silica fume, the results be too close to the optimum percentage. Therefore, it is clear that when silica fume added to cement mortar the optimum percentage can be used is $10 \%$ of cement content, it resulted in a significant change in the compressive strength of the mix. This is mainly due to the aggregate-paste bond improvement and enhanced microstructure. The addition of silica fume to mortar resulted in an improved bond between the hydrated cement matrix and sand in the mix, hence increasing strength. This improved bond is due to the conversion of the calcium hydroxide, which tends to form on the surface of aggregate particles, into calcium silicate hydrate due to the presence of reactive silica. The mix containing $15 \%$ silica fume as cement replacement showed maximum compressive strength with an increase of $30.8 \%$ at 28 -day control mix without silica fume. The increase in strength for $10 \%$ silica fume was found $10 \%, 16.1 \%$ and $28.8 \%$ for the 3,7 and 28 th days respectively compared to control one. Flow test results refer to a reduction in workability with increasing silica fume percentage until $10 \%$ then there is almost no reduction at $15 \%$ of silica fume replacement as shown in figure (7). Flexure strength had the same trend line for increasing strength with increasing silica fume percentage as flexure strength increase by 7.8, 14.5 and $20 \%$ at 3, 7, and 28-days respectively for $10 \%$ silica fume replacement and by $11.2,22.2$ and $26.8 \%$ at 3, 7, and 28-days respectively for $15 \%$ silica fume replacement as shown in figure (6).

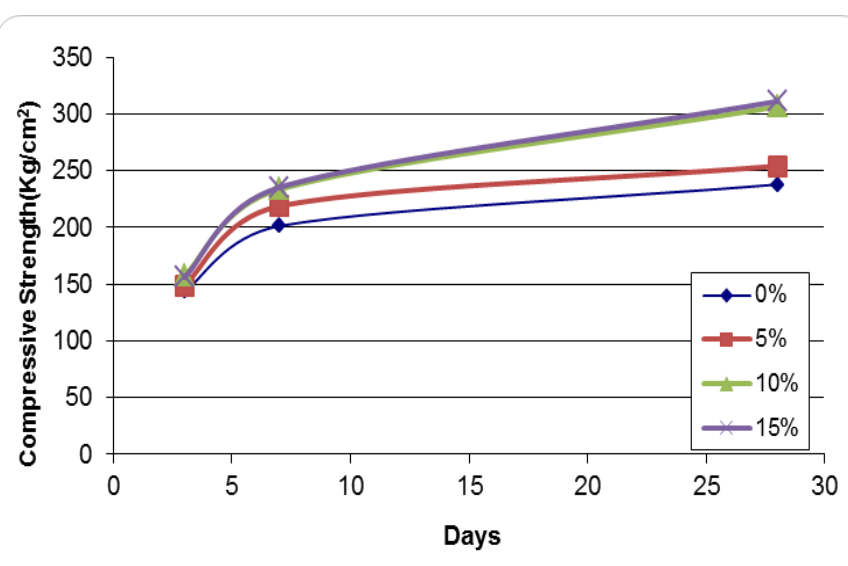

Fig.5. Effect of silica fume on cement mortar compressive strength

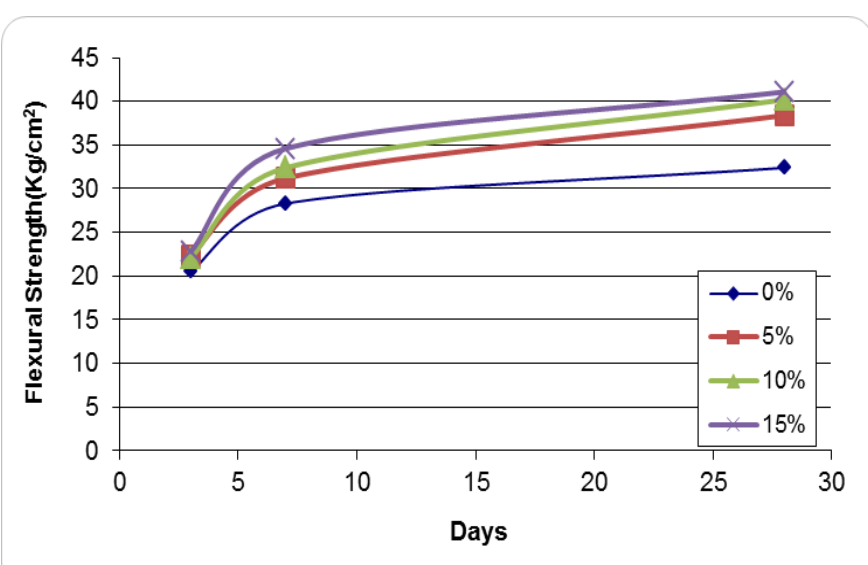

Fig.6. Effect of silica fume on cement mortar flexural strength

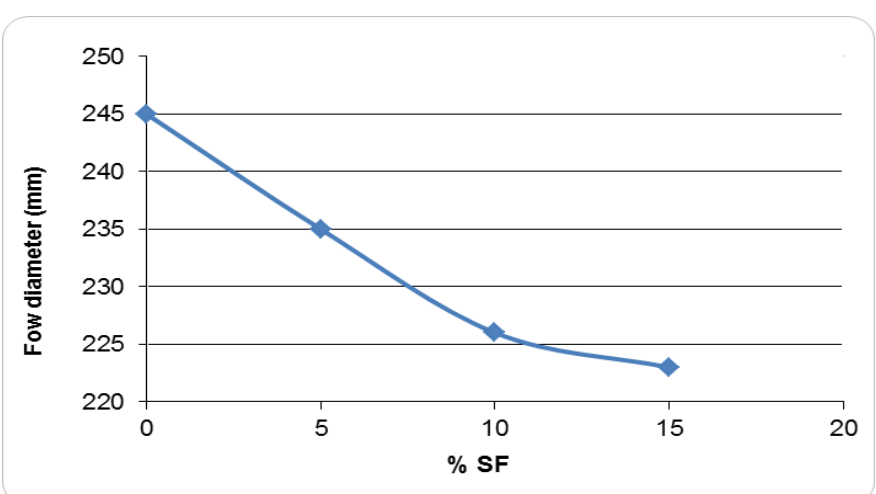

Fig.7. Effect of silica fume on cement mortar flow diameter

\section{IV.II. Effect of Fly ash /Cement Percentage (FA/C \%)}

The compressive strength development of cement mortar containing various levels of fly ash presented in fig. 8 as expected, at early age, the compressive strength of the mortar decreases with the increase amount of fly ash. The decrease in the 3 day strength of mortar mixes are proportionate to the fly ash content, where strength of the mortar with 5,10 , and $15 \%$ fly ash was lower by $4,1.5$ and $4.8 \%$ respectively. This behavior changed with curing time. At the age of 28 days, it is found that the cement mortar containing 5, 10 and $15 \%$ of fly ash exceeded the compressive strength of the plain mortar by $0.88,6.9$ and $2.2 \%$ respectively as shown in figure (8). Figure (9) show the flexure strength for cement mortar containing 0 , 5,10 and $15 \%$ fly ash, results give indicate that flexure strength decrease with increase fly ash content at early age but its increase by increasing fly ash at 28-days till $10 \%$, this results was compatible with compressive strength results. As shown in figure (10), Workability increase with increasing fly ash content in cement mortar. It is interesting to note that high volume fly ash often needs more than 7 days to acquire strength close to the plain concrete one. The continued increase in strength has been attributed to the by-product behavior of the ash, which endures to react with the cement to produce calcium silicate hydrate in presence of water. 
International Journal of Engineering Research and Technology. ISSN 0974-3154, Volume 13, Number 8 (2020), pp. 1909-1916

(C) International Research Publication House. https://dx.doi.org/10.37624/IJERT/13.8.2020.1909-1916

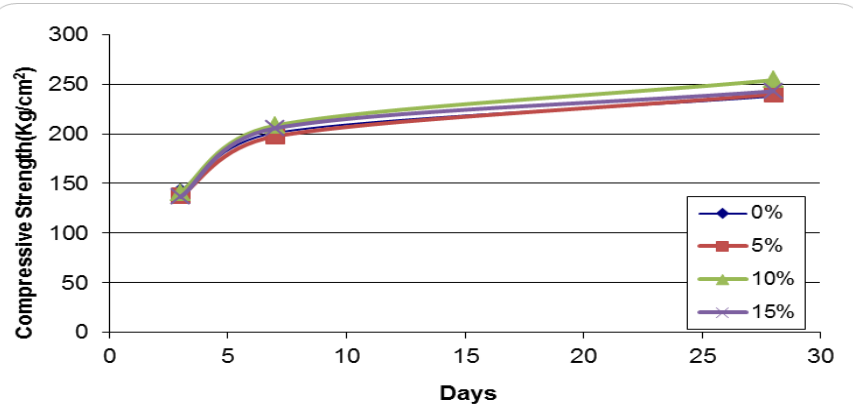

Fig.8. Effect of fly ash on cement mortar compressive strength

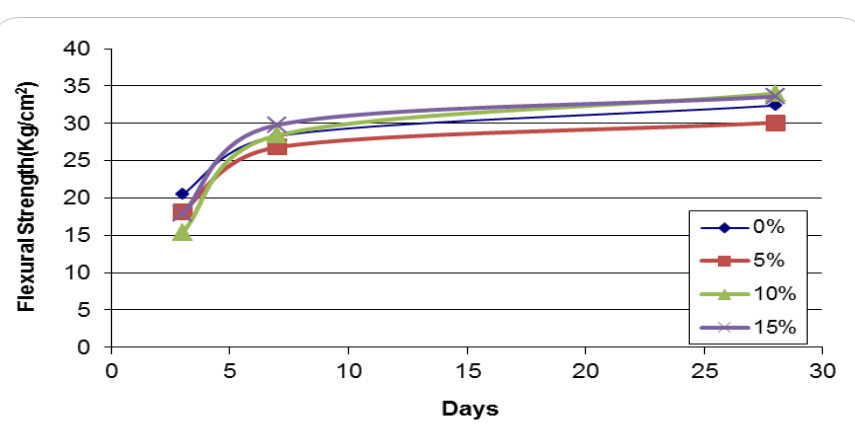

Fig.9. Effect of fly ash on cement mortar flexural strength

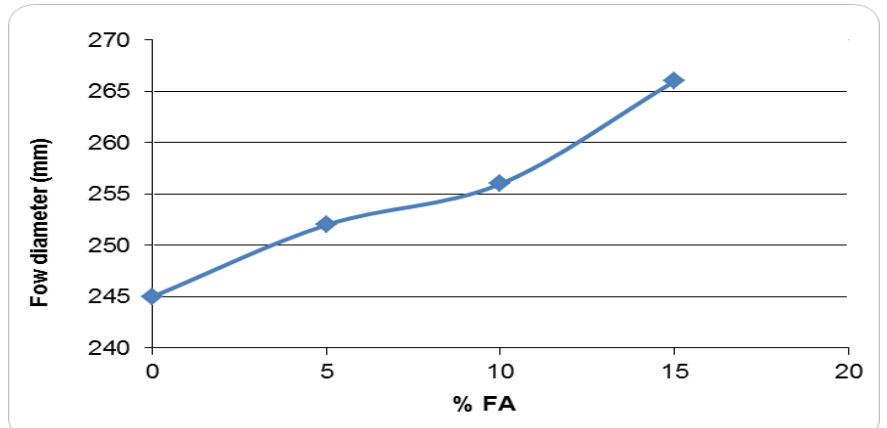

Fig.10. Effect of silica fume on cement mortar flow diameter

\section{IV.III. Effect of Fine Air-Cooled Slag /Cement Percentage (FACS/C \%)}

Figures (11, 12 and 13) show the effect of using Fine Air Cooled Slag as a cement replacement with constant cement content. The figures show that the optimum percentage of Fine Air Cooled Slag was $15 \%$ except 3 days compressive strength as the increase was $1.4 \%$ and $1.55 \%$ for 7 and 28 days $\%$ respectively, for 5, 10, 20 and \% Fine Air Cooled Slag, the results reduce compared to control and optimum mix. Therefore, it is clear that when Fine Air Cooled Slag added to cement mortar the optimum percentage can be used is $15 \%$ of cement content as shown in figure (10a), it resulted in a significant change in the compressive strength of the mix. For flexure strength there is no enhancement at early ages (3 and 7 days), even for the percentage 15\% of Fine Air Cooled Slag results were too closed to control mix. Optimum percentage achieved at 28 days by $15 \%$ of Fine Air Cooled Slag as a cement replacement, with $7.4 \%$ increasing more than control mix. Cement mortar mixes workability decrease with Fine Air Cooled Slag percentages increasing until 15\%, then re-increase but still down the optimum and control mix.

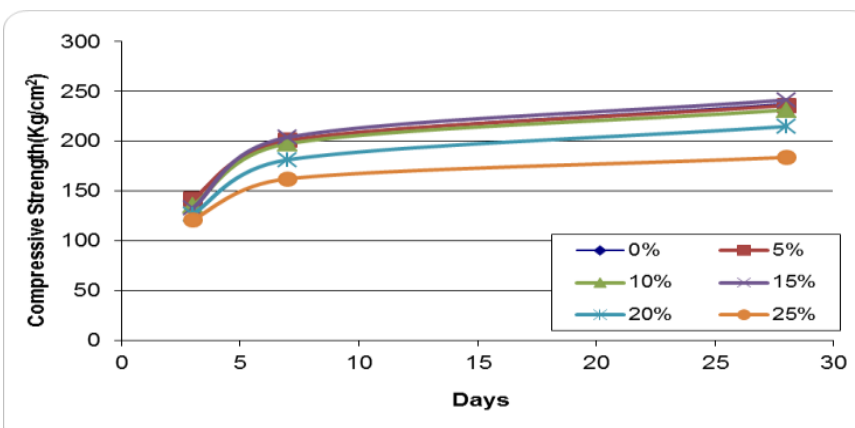

Fig.11. Effect of FACS on cement mortar compressive strength

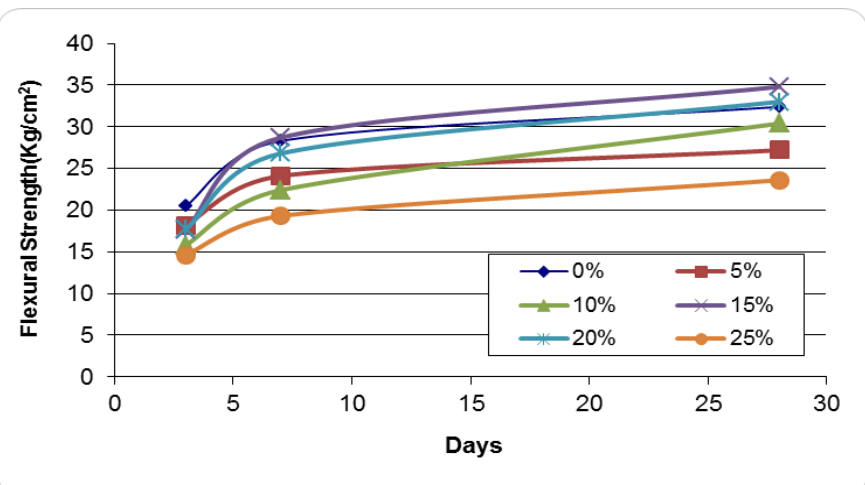

Fig.12. Effect of FACS on cement mortar flexural strength

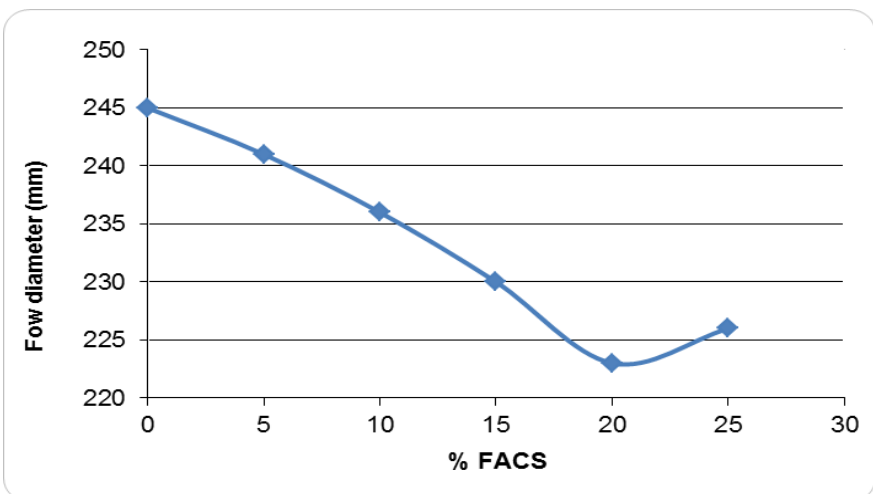

Fig.13. Effect of FACS on cement mortar flow diameter

\section{IV.IV. Effect of Nano Silica /Cement Percentage (NS/C \%)}

Figure 14 shows the effect using nano silica as cement replacement on the compressive and flexure strength and flow diameter on cement mortar mixes. As shown in the figure (14), the compressive strength at age 3, 7 and 28-days increases with increasing of nano silica percentage. The strength increases till about 3\% then decrease till $7 \%$. For the tested mixes, the optimum mix were replacing cement by $3 \%$ 
International Journal of Engineering Research and Technology. ISSN 0974-3154, Volume 13, Number 8 (2020), pp. 1909-1916

(C) International Research Publication House. https://dx.doi.org/10.37624/IJERT/13.8.2020.1909-1916

nano silica as compressive strength increase by $26.4,34.4$ and $38.5 \%$ at 3,7 and 28-days respectively. For flexure strengthincreasing trend were almost the same to compressive strength with different value as optimum percentage also $3 \%$, as flexure strength increase by $25.3,30$ and $33 \%$ at 3,7 and 28days, respectively as shown in figure (15). Workability clearly decreases with increasing nano silica percentage for all tested mixes as shown in figure (16).

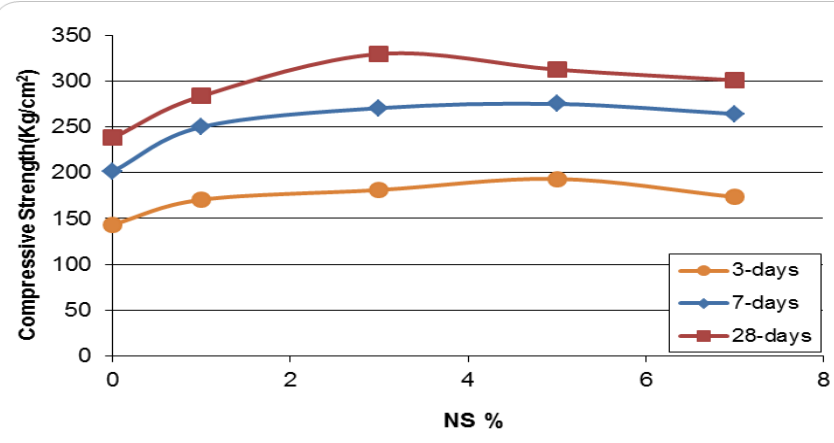

Fig.14. Effect of NS on cement mortar compressive strength

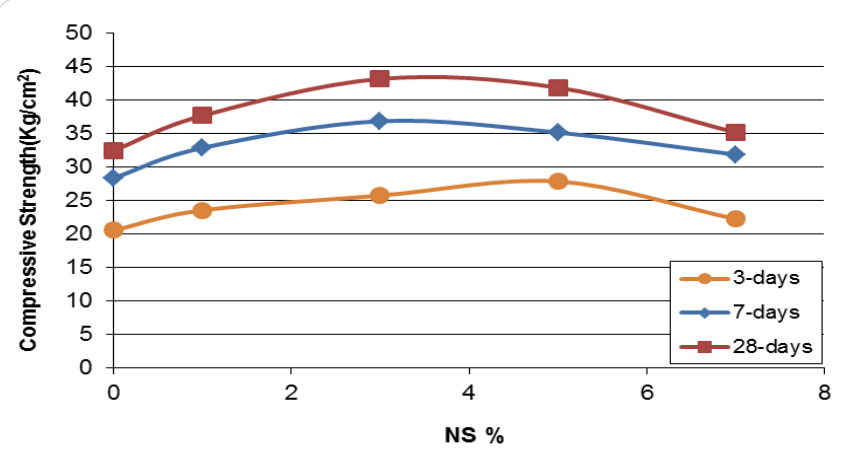

Fig.15. Effect of NS on cement mortar flexural strength

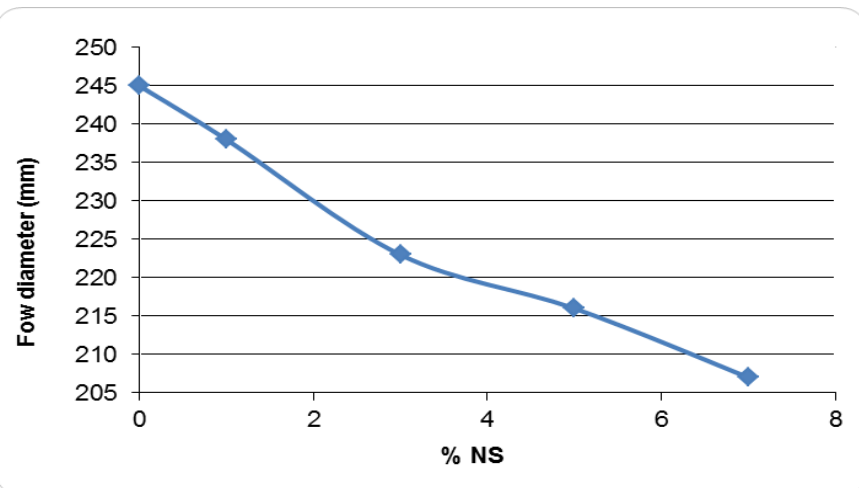

Fig.16. Effect of NS on cement mortar flow diameter

\section{IV.IV. Effect of Activated Nano Clay /Cement (ANC/C \%)}

As shown in figure (17), the compressive strength at age 3, 7 and 28-days increases with increasing of activated nano clay percentage. The strength increases until about $3 \%$ then decrease till $7 \%$. For the tested mixes, the optimum mix were replacing cement by $5 \%$ activated nano-clay as compressive strength increase by $20.4,33.4$ and $32.7 \%$ at 3, 7 and 28 -days respectively. For flexure strength-increasing trend were almost the same to compressive strength with different value as optimum percentage also $5 \%$, as flexure strength increase by $37,43.1$ and $58.3 \%$ at 3,7 and 28-days, respectively as shown in figure (18). Workability clearly decreases with increasing nano silica percentage for all tested mixes as shown in figure (19).

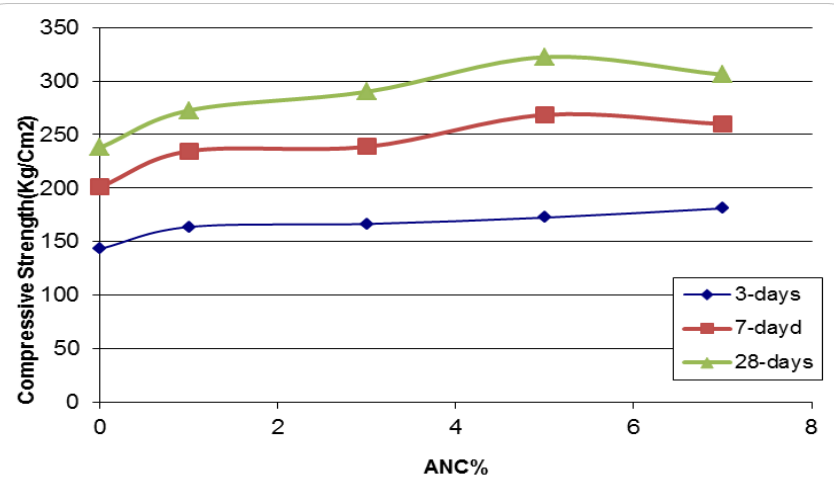

Fig.17. Effect of ANC on cement mortar compressive strength

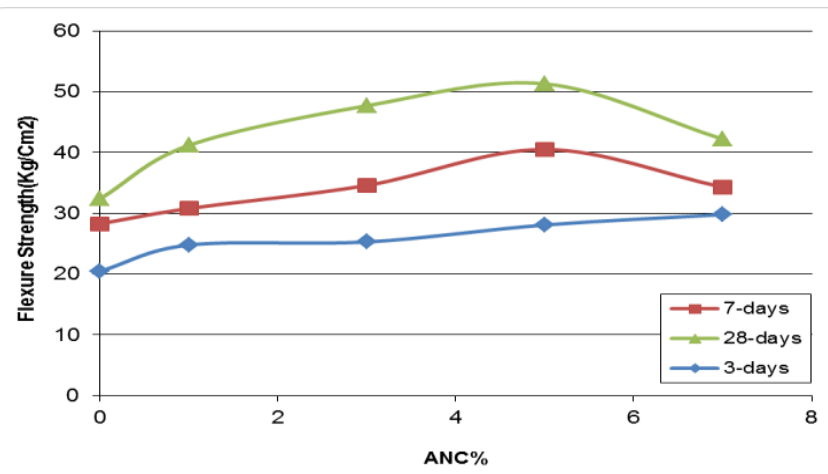

Fig.18. Effect of ANC on cement mortar flexural strength

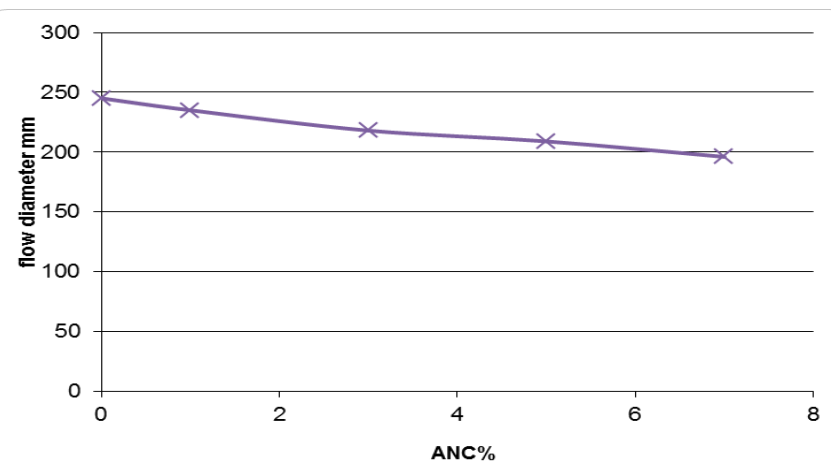

Fig.19. Effect of ANC on cement mortar flow diameter

\section{IV.V. Microstructure characterization with Scanning Electron Microscope (SEM)}

Figures $(20 a, b)$ show the SEM micro-graphs of the cement mortar samples with ordinary Portland cement and the mortar containing $3 \% \mathrm{NS}$ as cement replacement. As it can be seen in 
figure (20a), the SEM images show the microstructure characteristics of cement paste, few micro pores have been observed and less homogenity in micro and nano scale. Using $3 \%$ activated nano-clay (ANC) as cement replacement create homogenous $\mathrm{C}-\mathrm{S}-\mathrm{H}$ gel with good bonding characteristics, which explain the improvement in cement mortar samples strength more than all other materials used in this research as shown in figure (20b).

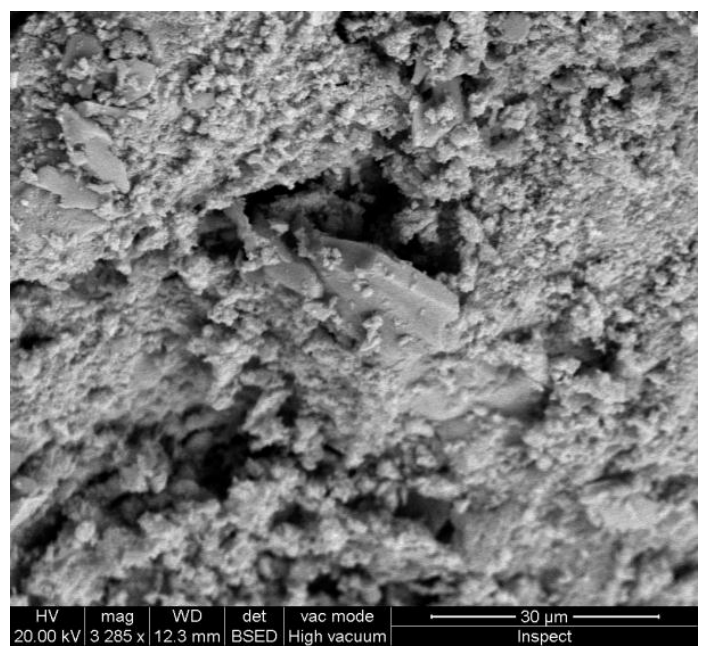

Fig.20a. SEM micrograph of control reference mix

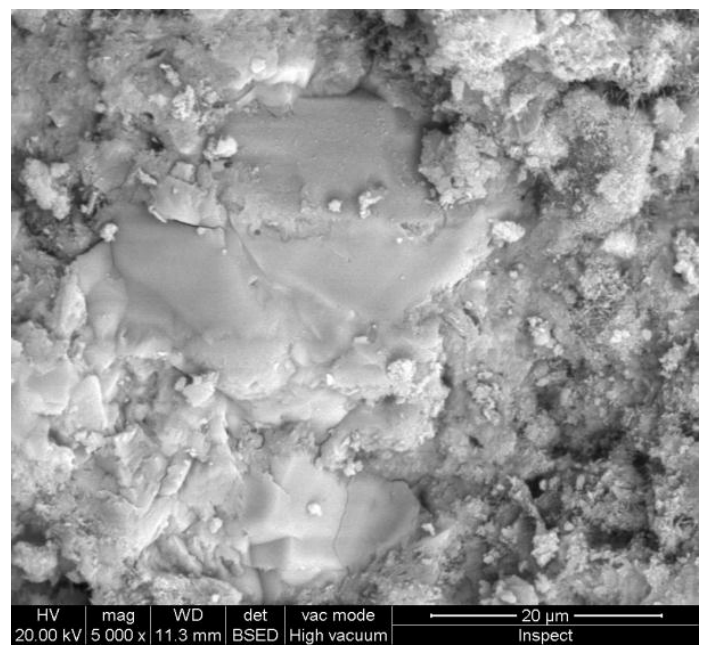

Fig.20b. SEM micrograph of 3\% NS-modified mortar

\section{CONCLUSION}

As the study aimed to produce green mortar, so more reduction in cement content mean more green product and less pollution and less cost, especially with more improvement in the product cement mortar properties such as compressive and flexural strength, that mean best results were using byproduct materials then nano-clay, finally nano-silica. Using byproduct materials not only aimed to reduce cement content, but also helping in reduce environmental pollution caused by such materials. Also the product green cement mortar becomes more durable, denser and sustainable for construction purposes.
Cement mortar mechanical properties such as compressive, flexure strength and workability had a noticed improved were using local byproduct and nano-materials as a partially cement replacement, such as, silica fume, fly ash, fine air-cooled slag, nano silica and activated nano-clay. Compressive strength is the main indicator for the other properties, as its improving directly refers to an enhancement for the other properties. Test results and optimum percentage briefly, as Compressive strength increase by $30.8,6.9,1.55,38.5$ and $32.7 \%$, more than control mix when use $15 \% \mathrm{SF}, 10 \%$ FA, $15 \%$ FACS, $3 \%$ NS and 7\% ANC, respectively. Flexure strength increase by $26.8,4.9,7.4,33$ and $58.3 \%$, more than control mix when use $15 \%$ SF, $10 \%$ FA, $15 \%$ FACS, $3 \%$ NS and 5\% ANC, respectively. Workability for product green cement mortar decrease when using silica fume, fine air cooled slag nanosilica and nano-clay, but it increases when using fly ash and marble dust with selected optimum percentage.

\section{ACKNOWLEDGMENT}

The research is part of $\mathrm{PhD}$ thesis, which submitted to the Department of Structural Engineering, Faculty of Engineering, Cairo University.

\section{REFERENCES}

[1] Liew KM, Sojobi AO, Zhang LW. Green concrete: Prospects and challenges. Construction and building materials. 2017 Dec 15;156:1063-95.

[2] Al-Jabri K, Shoukry H. Use of nano-structured waste materials for improving mechanical, physical and structural properties of cement mortar. Construction and Building Materials. 2014 Dec 30;73:636-44.

[3] Shoukry H, Shebl SS, Khalil IS. Preparation of ultrafine silica particles and their application for enhanced strength of cement mortar. Cement Wapno Beton. 2014 Jan 1;81:17-22.

[4] Morsy MS, Shoukry H, Mokhtar MM, Ali AM, ElKhodary SA. Facile production of nano-scale metakaolin: An investigation into its effect on compressive strength, pore structure and microstructural characteristics of mortar. Construction and Building Materials. 2018 May 30;172:243-50.

[5] Imbabi MS, Carrigan C, McKenna S. Trends and developments in green cement and concrete technology. International Journal of Sustainable Built Environment. 2012 Dec 1;1(2):194-216.

[6] Shoukry H, Kotkata MF, Abo-EL-Enein SA, Morsy MS, Shebl SS. Enhanced physical, mechanical and microstructural properties of lightweight vermiculite cement composites modified with nano metakaolin. Construction and Building Materials. 2016 Jun 1;112:276-83.

[7] Shoukry H, Kotkata MF, Abo-EL-Enein SA, Morsy MS, Shebl SS. Thermo-physical properties of nanostructured lightweight fiber reinforced 
cementitious composites. Construction and Building Materials. 2016 Jan 15;102:167-74.

[8] Naqi A, Jang JG. Recent progress in green cement technology utilizing low-carbon emission fuels and raw materials: A review. Sustainability. 2019 Jan;11(2):537.

[9] Al-Jabri K, Shoukry H, Abdel Aal A. Physicomechanical properties of lime-silica fume pastes modified with nano-metakaolin. Proceedings of the Institution of Civil Engineers-Structures and Buildings. 2019 Mar 22:1-9.

[10] Al-Jabri K, Shoukry H. Influence of nano metakaolin on thermo-physical, mechanical and microstructural properties of high-volume ferrochrome slag mortar. Construction and Building Materials. 2018 Jul 20;177:210-21.

[11] Ibrahim MI, Mohamed NA. Towards sustainable management of solid waste in Egypt. Procedia Environmental Sciences. 2016 Jan 1;34:336-47.

[12] Ramadan AR, Sherif Y. Hazardous waste management in Egypt: performance indicators for industry. WIT Transactions on Ecology and the Environment. 2008 May 20;109:349-59.

[13] Ibrahim MI, Mohamed NA. Towards sustainable management of solid waste in Egypt. Procedia Environmental Sciences. 2016 Jan 1;34:336-47.

[14] Shin KJ, Carboneau N. The Indiana local technical assistance program roller compacted concrete pavement manual for local government agencies.

[15] El-Sayed HA, Farag AB, Kandeel AM, Younes AA, Yousef MM. Characteristics of the marble processing powder waste at Shaq El-Thoaban industrial area, Egypt, and its suitability for cement manufacture. HBRC journal. 2018 Aug 1;14(2):171-9.

[16] Shebl SS, Khalil IS, Shoukry H. Using of Microsilica for Strength Improvement of Fiber Reinforced Cementitious Surface Compounds. International Scholarly Research Notices. 2013;2013.

[17] Sharma N, Kumar R. Use of waste marble powder as partial replacement in cement sand mix. International Journal of Engineering Research \& Technology. 2015 May;4(5):501-4.

[18] - Ibrahim Sobhy Khalil (2013) "Effect of Using NanoSilica Particles on the Properties of Different Concrete Mixes" Submitted in partial fulfillment for the Requirements of the Master of Science in Structural Engineering, Helwan University, Cairo, Egypt.

[19] Shoukry H. Development of Nano Modified EcoFriendly Green Binders for Sustainable Construction Applications. InNano Hybrids and Composites 2019 (Vol. 24, pp. 25-36). Trans Tech Publications Ltd.

[20] Reddy TV, Rajasekhar K, Janardhana S. Study and Performance of High Strength Concrete Using with Nano Silica and Silica Fume. International Journal of
Civil Engineering and Technology. 2015;6(11).

[21] Rupasinghe M, San Nicolas R, Mendis P, Sofi M. Analysing the pozzolanic reactivity of nano-silica in cement paste.

[22] Morsy MS, Rashad AM, Shoukry H, Mokhtar MM. Potential use of limestone in metakaolin-based geopolymer activated with $\mathrm{H} 3 \mathrm{PO} 4$ for thermal insulation. Construction and Building Materials. 2019 Dec 30;229:117088.

[23] Sayed Abd EL-Baky, Sameh Yehia, Ibrahim S. Khalil, (2013), "INFLUENCE OF NANO-SILICA ADDITION ON PROPERTIES OF FRESH AND HARDENED CEMENT MORTAR", 5th International Conference, NANOCON, 2013, Brno, Czech Republic, EU.

[24] Egyptian code of practice for design of concrete structures (ECP203-2007).

[25] ASTM C136 - 14, (2014), "Standard Test Method for Sieve Analysis of Fine and Coarse Aggregates" American Society for Testing and Materials Standard Practice C136 - 14, Philadelphia, PA, 2014

[26] ASTM C618 - 12a, (2012), "Coal Fly Ash and Raw or Calcined Natural Pozzolan for Use in Concrete1," American Society for Testing and Materials Standard Practice C618 - 12a, Philadelphia, PA, 2013

[27] ASTM E 2456-06, (2006), “Terminology for Nanotechnology," American Society for Testing and Materials Standard Practice E 2456-06 , Philadelphia, PA, 2006.

[28] ASTM C 109/ C 109M-16a, "Standard Test Method for Compressive Strength of Hydraulic Cement mortars (Using 2-in. or [50-mm] Cube Specimens)" .

[29] - ASTM C348-18, "Standard Test Method for flexural strength of Hydraulic-cement mortar" 